\title{
LingTera
}

Volume 2 - Nomor 2, Oktober 2015, (222 - 232)

Available online at LingTera Website: http://journal.uny.ac.id/index.php/ljtp

\section{PENGEMBANGAN BAHAN AJAR KETERAMPILAN BERBICARA BAHASA JEPANG BERORIENTASI BUDAYA MATA KULIAH KAIWA TINGKAT MENENGAH}

\author{
Sri Wahyu Widiati ${ }^{1)}$, Sugirin ${ }^{2)}$ \\ Universitas Riau ${ }^{1)}$, Universitas Negeri Yogyakarta ${ }^{2)}$ \\ sw_widiati@yahoo.co.jp ${ }^{1)}$,psugirin12@gmail.com ${ }^{2)}$
}

\begin{abstract}
Abstrak
Penelitian ini bertujuan: (1) mengembangkan bahan ajar yang sesuai untuk keterampilan berbicara bahasa Jepang tingkat menengah dengan mengangkat tema-tema kebudayaan Jepang dan Indonesia, yang memadukan empat keterampilan berbahasa dengan fokus utama pada keterampilan berbicara; (2) mengetahui tingkat kelayakan bahan ajar yang dikembangkan. Jenis penelitian ini adalah penelitian dan pengembangan. Prosedur pengembangan produk terdiri dari: (1) pengumpulan data pada survei kebutuhan, (2) perencanaan, (3) pengembangan produk, (4) validasi (uji ahli, uji coba terbatas, uji coba lapangan) dan revisi, dan (5) produk akhir. Bahan ajar terdiri dari lima unit dan disertai VCD. Hasil validasi oleh ahli menunjukkan bahwa nilai rata-rata materi adalah 4.76 dengan kategori 'sangat baik' dan nilai rata-rata media adalah 4.31 dengan kategori 'sangat baik'. Kesimpulan dari penelitian ini adalah bahan ajar yang dikembangkan layak untuk digunakan di dalam kegiatan pembelajaran.
\end{abstract}

Kata kunci: bahan ajar berorientasi budaya, keterampilan berbicara, Kaiwa, bahasa Jepang tingkat menengah.

\section{DEVELOPING A CULTURE-ORIENTED JAPANESE LANGUAGE LEARNING MATERIALS FOR SPEAKING SKILL OF INTERMEDIATE KAIWA LESSON}

\begin{abstract}
This study aims to: (1) develop appropriate learning materials for intermediate Japanese Language speaking skill by adapting Japanese and Indonesian culture themes, which integrate four language skills focusing on the speaking skill; (2) reveal the properness level of the learning materials. This is a research and development study. The steps of conducting the study were (1) collecting the data on needs analysis, (2) planning, (3) developing the product, (4) validating (expert judgment, preliminary field testing, main field testing) and revising, (5) writing the final draft of the learning materials. The learning materials consist of five units accompanied with a VCD. The result of the expert judgment shows that the material is in the average score of 4.76 which is in the very good category. The result of the expert judgment on the media is in the average score of 4.31 which is in the very good category. The conclusion of this study is that the learning materials are appropriate to be implemented in the learning activities.
\end{abstract}

Keywords: culture-oriented learning materials, speaking skills, kaiwa, intermediate Japanese language 


\section{LingTera, 2 (2), Oktober 2015 - 223}

Sri Wahyu Widiati, Sugirin

\section{PENDAHULUAN}

Salah satu strategi untuk meningkatkan kualitas pembelajaran bahasa adalah melalui bahan ajar. Dalam pembelajaran bahasa Jepang, buku ajar yang digunakan umumnya merupakan terbitan Jepang, sehingga masih sangat diperlukan pengembangan buku ajar atau bahan ajar yang menyesuaikan dengan kebutuhan pembelajar atau peserta didik di Indonesia.

Jika merujuk pada konten budaya, maka kesempatan peserta didik untuk berlatih berbicara mengenai budaya asal dan budaya target masih perlu ditingkatkan. Hal ini dikarenakan belum terdapat bahan ajar yang mengangkat konten kebudayaan Jepang dan Indonesia dengan kuantitas yang seimbang.

Dalam mempelajari bahasa asing, peserta didik diharapkan tidak hanya mempelajari budaya asing tersebut, tetapi juga mampu menggunakan kompetensi berbahasa yang dimiliki untuk memperkenalkan dan mempertahankan kebudayaan bangsa sendiri. Indonesia dan Jepang sama-sama memiliki potensi kebudayaan yang sangat besar dan menarik untuk diangkat sebagai materi pembelajaran.

Bahan ajar yang mengintegrasikan bahasa dan budaya, berjalan paralel di dalam mencapai target pembelajaran. Kompetensi bahasa ditingkatkan berdasarkan metode pembelajaran tertentu, dan tema-tema kebudayaan diangkat sebagai konten materi guna meningkatkan wawasan para peserta didik.

The textbook is a powerful medium for cultural sustenance and literacy development. The language textbook in particular is vital to making culture relevant to intellectual development. (Olajide, 2010, p.656).

Pernyataan tersebut menunjukkan bahwa buku ajar atau bahan ajar merupakan sebuah media yang sangat penting. Dalam hal ini sebagai upaya untuk meningkatkan pembelajaran bahasa sekaligus mempertahankan kebudayaan. Hal-hal yang disebutkan mendasari dilakukannya penelitian ini. Produk pembelajaran yang dikembangkan pada penelitian ini merupakan suatu bahan ajar yang berorientasi budaya.

Bahan ajar bahasa Jepang yang memuat tema-tema budaya Jepang dan Indonesia akan bermanfaat baik bagi pembelajar Indonesia maupun pembaca yang merupakan orang Jepang. Bagi pembelajar Indonesia, selain dapat mempelajari budaya Jepang, juga dapat mempelajari budaya sendiri yang dikemas di dalam bahasa Jepang. Bahan ajar berorientasi budaya akan menyajikan referensi kosakata, ungkapan, maupun kalimat berbahasa Jepang yang dapat dirujuk untuk berlatih menyampaikan informasi tertentu mengenai budaya.

Pembelajaran melalui bahan ajar ini juga akan bermanfaat jika para peserta didik berpeluang untuk belajar ke Jepang. Hal ini dikarenakan bahan ajar ini dapat menjadi sumber informasi untuk memperkenalkan kebudayaan Indonesia, dan mempersiapkan wawasan mengenai kebudayaan Jepang. Demikian pula sebaliknya bagi pembaca asli Jepang yang membutuhkan referensi mengenai kebudayaan Indonesia.

Kompetensi berbahasa peserta didik yang paling perlu mendapat perhatian untuk mendukung hal tersebut adalah kompetensi berbicara. Hal ini dikarenakan, pada situasi yang sebenarnya, peserta didik akan lebih banyak terlibat langsung di dalam kegiatan berbicara untuk mengkomunikasikan atau menyampaikan pesan-pesan mengenai kebudayaan.

Mengingat luasnya konten mengenai kebudayaan, maka keterampilan berbicara yang akan dibina perlu didukung dengan keterampilan berbahasa lainnya. Melalui pembelajaran yang terpadu, informasi-informasi mengenai kebudayaan akan dapat lebih banyak diperoleh oleh peserta didik.

Sebagaimana yang dinyatakan oleh Kaplan \& Manners (1999, p.4), culture diakui sebagai suatu istilah yang omnibus, mahaluas pengertiannya. Oleh karena itu, bahan ajar yang dikembangkan dengan orientasi budaya, harus memiliki sebuah batasan tertentu.

Konsep budaya yang menjadi orientasi bahan ajar penelitian ini adalah cross cultural knowledge. Maksudnya adalah pengetahuan lintas budaya yang merujuk pada tingkat permukaan kebudayaan seperti karakteristik kebudayaan, kepercayaan, perilaku, nilai, tradisi, dan sebagainya.

Honigmann (1959) membedakan gejala kebudayaan ke dalam tiga hal, yaitu: (1) ideas, (2) activities, dan (3) artifacts (dalam Koentjaraningrat, 2009, p.150). Sebagaimana yang dikutip oleh Azlina Murad Sani, Robinson (1988) membedakan elemen budaya ke dalam kategori-kategori sebagai berikut: "product" (contoh: cerita rakyat, seni, artefak), "attitude" (adat/kebiasaan, makanan, gestur) dan "ideas" (contoh: kepercayaan, nilai) (dalam Tickoo, 1995, p.253). 
Berbagai teknik pembelajaran dapat diterapkan untuk memberikan wawasan kebudayaan kepada peserta didik. Salah satu saran teknik pembelajaran tersebut adalah sebagai berikut: (1) use the literature to explore culture (menggunakan literatur untuk mengeksplorasi budaya); (2) use the arts to explore culture (menggunakan kesenian untuk mengeksplorasi budaya); (3) surround students with stimuli from the target culture (berikan kepada para pembelajar stimulus-stimulus yang berkaitan dengan budaya target); (4) assign students to present research on the target culture (berikan tugas pada pembelajar untuk mempresentasikan penelitian mengenai budaya target); (5) include problemsolving skills to help discover culture (masukkan keterampilan menyelesaikan masalah untuk membantu pembelajar menjelajah budaya); (6) engage students in role plays, dramas, and simulations (pasangkan para pembelajar di dalam permainan peran, drama, dan simulasi); (7) get students involved through experiential learning and contact assignments (libatkan pembelajar di dalam pembelajaran pengalaman dan tugas-tugas melakukan kontak); (8) introduce holidays, festivals, and religious traditions (perkenalkan liburan-liburan, festival, dan tradisi-tradisi keagamaan) (Wintergerst \& McVeigh, 2011, p.120).

Berdasarkan keterampilan berbahasa yang menjadi fokus pengembangan pada penelitian ini, yaitu keterampilan berbicara, maka perlu merujuk pada hakikat berbicara itu sendiri. Pengertian secara terperinci mengenai berbicara dapat membantu membangun panduan untuk pembelajaran formal keterampilan berbicara. Hiesuji Shobou merumuskan pengertian kegiatan berbicara dan kaitannya dengan latihan berbicara di dalam kelas, sebagaimana yang tertera berikut ini:

$$
\begin{aligned}
& \text { 話す行為は、言いたい内容を考え、言い } \\
& \text { たい表現を選び、音声に出して相手に伝 } \\
& \text { えるといらプロセスをたとります。話し } \\
& \text { 手と聞き手の } \\
& \text { コミュニケーションは、「目的」と「情 } \\
& \text { 報差」、「選択権」、 } \\
& \text { 「反応」からなています。この、話す } \\
& \text { プロセスとコミュニケー ションの } \\
& \text { 要素を、教室における練習との関係で考 } \\
& \text { えました (Hiesuji, 2007, p.11). }
\end{aligned}
$$

Berbicara merupakan sebuah kegiatan yang mengikuti proses-proses seperti berpikir hal yang ingin diutarakan, memilih ragam atau ekspresi, mengeluarkannya dalam bentuk bunyi, dan menyampaikan hal tersebut pada lawan bicara. Komunikasi antara pembicara dan lawan bicara melibatkan 'maksud', 'kesenjangan informasi', 'hak memilih', dan 'respon'. Faktor-faktor pada proses berbicara dan komunikasi harus diperhatikan di dalam kegiatan-kegiatan yang berhubungan dengan latihan yang diselenggarakan di kelas (Hiesuji, 2007, p.11)

Kegiatan latihan berbicara di dalam kelas dapat divariasikan menurut karakteristik-karakteristik yang terdapat di dalam masing-masing fungsi berbicara. Tiga macam fungsi berbicara yang dimaksud adalah talk as interaction, talk as transaction, talk as performance (Richards, 2008, p.21). Hal ini tidak terlepas dari pembelajaran yang menghubungkan dengan bentukbentuk kegiatan berbicara pada situasi sebenarnya.

Dalam strategi pengajaran, pemakaian beberapa teknik dipandang lebih menguntungkan daripada hanya menggunakan satu teknik saja. Demikian pula dalam hal pendekatan, digunakan secara bervariasi antara pendekatan terkontrol dan pendekatan bebas. Kedua pendekatan ini dapat diberlakukan pada sejumlah teknik yang dikehendaki, misalnya: (1) Berbicara terpimpin; frase dan kalimat, satuan paragraf, dialog, pembacaan puisi. (2) Berbicara semiterpimpin; reproduksi cerita, cerita berantai, menyusun kalimat dalam pembicaraan, melaporkan isi bacaan secara lisan. (3) Berbicara bebas; diskusi, drama, wawancara, berpidato, bermain peran (Iskandarwassid \& Sunendar, 2011, pp.244-245).

Sesuai dengan kebutuhan pembelajaran yang diketahui melalui needs analysis, pengembangan bahan ajar keterampilan berbicara berorientasi budaya pada penelitian ini membutuhkan perpaduan seluruh keterampilan berbahasa. Tujuannya agar pesan mengenai materi budaya tersampaikan dengan efektif dan keterampilan berbicara dapat lebih optimal dengan bantuan keterampilan berbahasa lainnya.

Integratif berarti menyatukan beberapa aspek ke dalam satu proses. Dikatakan pula bahwa metode ini sebenarnya secara implisit hadir pada setiap pendekatan maupun metode. Oleh karena itu, dalam setiap perencanaan pengajaran, metode ini jarang dimunculkan sebagai metode tersendiri (Iskandarwassid \& Sunendar, 2011, p.61). 
Berikut ini adalah ilustrasi organisasi materi dalam pembelajaran terpadu yang diadaptasi dari Deni Kurniawan (Kurniawan, 2011, p.51). Ilustrasi ini menggambarkan konsep pembelajaran terpadu dalam pembelajaran bahasa Jepang dengan topik kebudayaan.

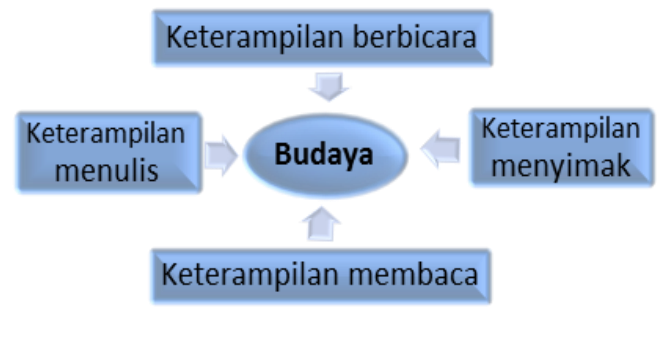

Gambar 1. Organisasi Materi

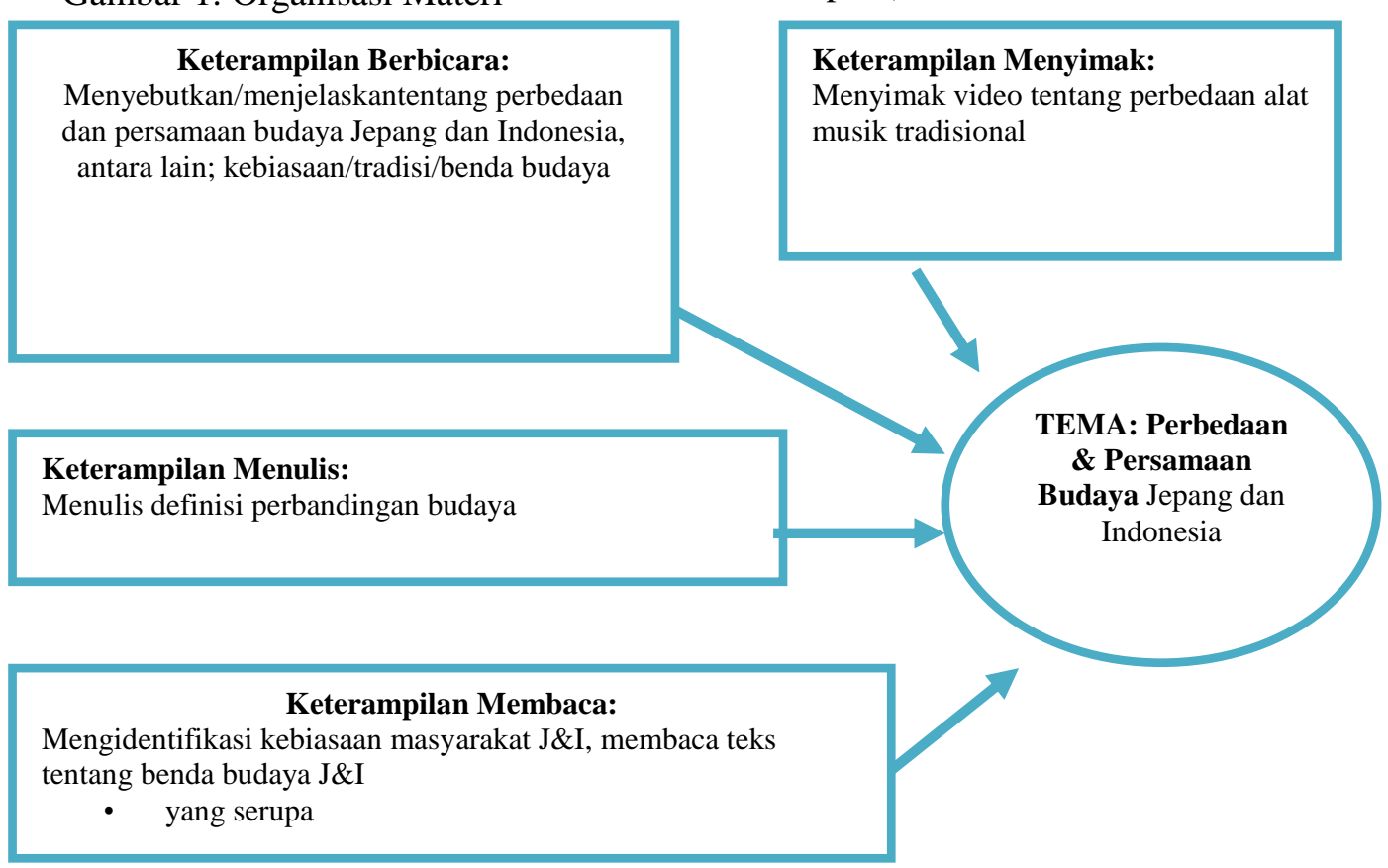

Gambar 2. Jaringan Tema

Dalam rangka mengoptimalkan latihan berbicara pada bahan ajar yang dikembangkan pada penelitian ini, maka ditambahkan pula implementasi konsep task-based instruction atau pengajaran berbasis tugas. Setelah menstimulus pembelajar dengan wawasan budaya, latihanlatihan yang disajikan dikemas dengan konsep tersebut. Hal ini bertujuan agar para pembelajar dapat berinteraksi dan berkomunikasi secara alami di dalam kelas dengan mengangkat tema seputar budaya.

Task-based Instruction (TBI) merupakan salah satu pendekatan teknik mengajar bahasa di dalam metodologi pengajaran bahasa komunikatif (Communicative Language Teaching/ CLT). Materi dan kegiatan pembelajaran berbasis tugas atau task-based dapat berjalan
Organisasi materi pada bahan ajar berorientasi budaya yang dikembangkan, memadukan empat keterampilan berbahasa dengan tema budaya sebagai titik temu. Hal yang tidak tampak pada gambar berikut ini namun diimplementasikan pada bahan ajar adalah bahwa latihan-latihan keterampilan berbicara memiliki frekuensi yang lebih banyak.

Tema pada setiap latihan keterampilan berbahasa dapat bervariasi, namun masih berkaitan dengan tema besar pada setiap unit. Berikut ini adalah ilustrasi mengenai jaringan tema berorientasi budaya dengan memadukan empat keterampilan berbahasa. Jaringan tema ini diadaptasi dari Deni Kurniawan (Kurniawan, 2011, p.86).

Menyimak video tentang perbedaan alat adisional

dengan efektif jika disusun secara integratif sebagaimana yang telah dipaparkan pada bagian tersebut. Hal ini didasari oleh pendapat yang menyatakan "the need for such an integrated approach is one argument in favour of a taskbased syllabus" yang artinya adalah kebutuhan akan pendekatan berintegrasi seperti itu merupakan salah satu penjelasan untuk mendukung silabus berbasis tugas (Thornbury, 2005, p.119). Kemudian Thornbury menambahkan bahwa silabus berbasis tugas untuk berbicara akan berdasarkan rentetan tugas-tugas integratif, " $a$ task-based syllabus for speaking, then, would be based around a sequence of integrated tasks" (Thornbury, 2005, p.119).

Penelitian dan pengembangan ini berpijak pada fakta-fakta yang ditemukan pada survei 
kebutuhan yang dilakukan di Program Studi Bahasa dan Sastra Jepang, Fakultas Ilmu Budaya, Universitas Gadjah Mada, Yogyakarta. Bahan ajar akan diujicobakan pada perkuliahan Kaiwa 6 atau Berbicara 6, sehingga materi yang disajikan menyesuaikan dengan kebutuhan mata kuliah tersebut. Pada Kaiwa 6, tingkat materi bahasa Jepang yang dipelajari adalah tingkat menengah. Oleh karena itu, bahan ajar disusun dengan menggunakan materi bahasa Jepang tingkat menengah. Acuan kaidah kebahasaan yaitu gramatika untuk tingkat menengah pada bahan ajar ini adalah buku-buku ajar yang berjudul,

$$
\begin{aligned}
& \text { 「みんなの日本語中級Ｉ I 本冊」dan } \\
& \text { 「インドネシア人学生のための } \\
& \text { まなぼう ! 中級日本語表現文型 } \\
& \text { 日本語 } \\
& \text { 能力試験 } 2 \text { 級レベル」. }
\end{aligned}
$$

\section{METODE}

\section{Jenis Penelitian}

Jenis penelitian yang digunakan pada penelitian ini adalah penelitian dan pengembangan, atau yang sering disebut dengan $\mathrm{R} \& \mathrm{D}$ (Research and Development). Penelitian ini tergolong penelitian $\mathrm{R} \& \mathrm{D}$ yang sederhana, karena tidak sampai pada tahap publikasi dan juga bukan merupakan sebuah penelitian yang bersifat longitudinal.

\section{Langkah-langkah Pengembangan}

Prosedur pengembangan produk yang ditempuh pada penelitian ini mengadaptasi prosedur R \& D cycle yang dikembangkan oleh Borg dan Gall (1983, p.775). Prosedur tersebut dirumuskan sebagai berikut: (1) pengumpulan data, (2) perencanaan, (3) pengembangan produk, (4) validasi (uji ahli, uji coba awal/terbatas, uji coba lapangan) dan revisi, (5) menghasilkan produk akhir.

Tahapan pengumpulan data yang dimaksud adalah kegiatan survei kebutuhan dengan melakukan penyebaran kuesioner kepada mahasiswa dan dosen, serta menganalisa datadata yang diperoleh. Berikutnya, hasil survei kebutuhan dijadikan pedoman untuk melangkah pada tahap perencanaan yaitu dengan menyusun silabus.

Pada tahapan pengembangan produk, dilakukan desain atau penyusunan bahan ajar sebanyak lima unit. Materi yang dikembangkan mengacu pada standar bahasa Jepang tingkat menengah. Selain materi tertulis, juga dikem- bangkan sebuah media VCD yang berisi video untuk setiap unit.

Tahapan validasi dilakukan guna mengetahui tingkat kelayakan bahan ajar. Validasi oleh ahli dilakukan sebelum menggunakan bahan ajar pada perkuliahan, sedangkan validasi oleh peserta didik dan pengamat dilakukan setelah penggunaan bahan ajar. Setelah melakukan berbagai revisi dan evaluasi, maka dihasilkan produk akhir bahan ajar.

Ahli materi terdiri dari dua ahli yang menguasai bahasa Jepang. Ahli media terdiri dari tiga ahli. Ahli materi terdiri dari Bapak Shimizu Tomitaka dan Bapak Stedi Wardoyo, S.S, M.A. Kedua ahli tersebut merupakan dosen bahasa Jepang Universitas Gadjah Mada. Ahli media terdiri dari Bapak Herman Dwi Surjono, M.Sc, M.T., Ph.D. yang merupakan ahli media pembelajaran dari Universitas Negeri Yogyakarta, serta Bapak Shimizu Tomitaka dan Bapak Stedi Wardoyo, S.S, M.A yang merupakan ahli bahasa Jepang.

Melalui penilaian para ahli, akan diketahui apakah bahan ajar layak atau tidak digunakan untuk pembelajaran. Sebelum dilakukan kegiatan pembelajaran pada perkuliahan, disusun Rencana Pelaksanaan Pembelajaran (RPP) untuk masing-masing unit yang akan diujicobakan. RPP terlebih dahulu memperoleh persetujuan dari dosen pengampu sebelum diaplikasikan.

\section{Subjek Coba}

Subjek coba pada penelitian ini adalah mahasiswa yang mengikuti mata kuliah Kaiwa 6 (Berbicara 6), semester enam, tahun ajaran 2012/2013.

\section{Waktu dan Tempat Penelitian}

Penelitian dilakukan di program studi Bahasa dan Sastra Jepang, Fakultas Ilmu Budaya, Universitas Gadjah Mada. Pelaksanaan uji coba untuk mengimplementasikan bahan ajar yang telah dikembangkan terbagi atas dua kategori uji coba, yaitu uji coba terbatas dan uji coba lapangan. Uji coba terbatas disebut juga uji coba kelas kecil atau terbatas. Uji coba terbatas dilakukan pada kegiatan ekstrakurikuler percakapan atau kaiwa-kai untuk tingkat atas atau jookyuu. Uji coba lapangan merupakan uji coba pada perkuliahan sebenarnya yaitu Kaiwa 6 (Berbicara 6). Berikut ini adalah tabel yang menunjukkan waktu pelaksanaan kedua jenis uji coba tersebut: 
LingTera, 2 (2), Oktober 2015 - 227

Sri Wahyu Widiati, Sugirin

Tabel 1. Jadwal Uji Coba Terbatas

\begin{tabular}{ccccc}
\hline Pertemuan & Tanggal & Pukul & Kelas & Materi \\
\hline 1 & 2 Mei 2013 & $13.30-15.00$ & Ekstrakurikuler & Unit 1 \\
\hline
\end{tabular}

Tabel 2. Jadwal Uji Coba Lapangan

\begin{tabular}{ccccc}
\hline Pertemuan & Tanggal & Pukul & Kelas & Materi \\
\hline 1 & 16 Mei 2013 & $07.15-09.40$ & A & Unit 2 \\
2 & 16 Mei 2013 & $10.00-11.30$ & B & Unit 4 \\
3 & 23 Mei 2013 & $07.15-09.40$ & A & Lanjutan unit 2 dan unit 3 \\
4 & 23 Mei 2013 & $10.00-11.30$ & B & Lanjutan unit 4 \\
\hline
\end{tabular}

\section{Teknik Pengumpulan Data}

Pengumpulan data dilakukan pada saat survei kebutuhan, uji coba ahli, uji coba terbatas dan uji coba lapangan. Instrumen berupa instrumen wawancara, observasi, dan kuesioner. Datadata kualitatif berupa hasil wawancara dan observasi, sedangkan data-data kuantitatif diperoleh dari kuesioner.

Wawancara kepada dosen dilakukan pada saat survei kebutuhan, sedangkan wawancara pada peserta didik dilakukan setelah uji coba terbatas dan uji coba lapangan. Observasi oleh peneliti dilakukan sebanyak tiga kali pada perkuliahan semester sebelum dilakukan uji coba. Pada kegiatan uji coba, juga dilakukan observasi oleh dosen pengampu sebagai pengamat dengan mengisi lembar observasi dan kuesioner.

\section{Teknik Analisis Data}

Teknik analisis data yang dilakukan adalah mendeskripsikan data-data kualitatif dan menghitung hasil data-data kuantitatif. data yang mula-mula berupa skor, diubah menjadi data kualitatif (data interval) dengan skala lima. Adapun acuan pengubahan skor menjadi skala lima tersebut mengadaptasi konversi skor menurut Sukarjo (2008, p.101):

Tabel 3. Konversi Skor Skala Lima

\begin{tabular}{|c|c|c|c|}
\hline No & Interval Skor (i) & Nilai & Kategori \\
\hline 1 & $\mathrm{x}>\ddot{\mathrm{x}} \mathrm{i}+1.80 \mathrm{Sbi}$ & A & $\begin{array}{c}\text { Sangat } \\
\text { Baik }\end{array}$ \\
\hline 2 & $\begin{array}{c}\ddot{\mathrm{x}} \mathrm{i}+0.60 \mathrm{SBi}<\mathrm{x} \leq \ddot{\mathrm{x}} \mathrm{i}+ \\
1.80 \mathrm{SBi}\end{array}$ & B & Baik \\
\hline 3 & $\begin{array}{c}\ddot{\mathrm{x} i}-0.60 \mathrm{SBi}<\mathrm{x} \leq \ddot{\mathrm{x}} \mathrm{i}+ \\
0.60 \mathrm{SBi}\end{array}$ & $\mathrm{C}$ & Cukup \\
\hline 4 & $\begin{array}{c}\ddot{\mathrm{x}}-1.80 \mathrm{SBi}<\mathrm{x} \leq \ddot{\mathrm{x}} \mathrm{-}- \\
0.60 \mathrm{SBI}\end{array}$ & D & Kurang \\
\hline 5 & $\mathrm{x} \leq \ddot{\mathrm{x}} \mathrm{i}-1.80 \mathrm{SBi}$ & $\mathrm{E}$ & $\begin{array}{l}\text { Sangat } \\
\text { Kurang }\end{array}$ \\
\hline
\end{tabular}

\section{HASIL DAN PEMBAHASAN}

Bahan ajar yang dikembangkan terdiri dari lima unit dan sebuah VCD yang memuat lima buah video untuk setiap unit. Dari lima unit yang dikembangkan, hanya empat unit yang diujicobakan. Hal ini dikarenakan keterbatasan waktu uji coba. Dengan kata lain, $80 \%$ unit di dalam bahan ajar telah digunakan di dalam pembelajaran sesungguhnya.

Bahan ajar ini diberi judul 「日本とインドネシアの文化で学ぶ中級日 本語」. Arti judul tersebut di dalam bahasa Indonesia adalah "Belajar Budaya Jepang dan Indonesia dengan Bahasa Jepang Tingkat Menengah".

Tema kebudayaan pada setiap unit di dalam bahan ajar pada penelitian ini terdiri dari: (1)

Unit

1 第 1 課:「日本の地域による文化的の特

徵」"Kekhasan Budaya Menurut Daerah di Jepang"; (2) Unit 2 (第 2 課:「インドネシアの地域による文

化的な特徵」 "Kekhasan Budaya Menurut Daerah di Indonesia"; (3) Unit 3 (第 3 課:「後世に伝え

たい伝統的な遊び」”Permainan Tradisional Yang Ingin Diwariskan Kepada Generasi Muda"; (4) Unit 4 (第 4 課:「インドネシアと日本の文化の 共通点と相違点」"Persamaan dan Perbedaan Budaya Indonesia dan Jepang"; (5) Unit 5 (第 5 課:「日本とインドネシアの人格形 成」 "Pembentukan Karakter Bangsa Jepang dan Indonesia".

Adapun hasil pengembangan berupa media VCD, adalah sebagai berikut: (1) Video 1 berjudul 「長崎さ るく」”Jalan-jalan Di Nagasaki". Penulis naskah adalah Sri Wahyu Widiati, dan pengisi suara adalah Ueda Yusa;

$$
\text { Video }
$$

berjudul「パプア、黒い真珠の島」”Papua,

Pulau Mutiara Hitam". Penulis naskah adalah Sri Wahyu Widiati, pengisi suara adalah Ueda Yusa; (3) Video 3 berjudul「日本のお正月の遊び : 福笑い」”P 
ermainan Tahun Baru di Jepang: Fukuwarai”. Sumber:

http://www.youtube.com/watch?v=AWkbeZyb9

pg; (4) Video 4

berjudul「ガムランとは」”Yang Disebut

Dengan Gamelan".

Sumber:http://www.youtube.com/watch? $=\mathrm{Ngq}$

ZZjDI5Gs; (5) Video 5

berjudul「行列の魅力」”Daya Tarik Budaya

Mengantri".

Sumber:http://www.youtube.com/watch?v=JXK mdl0cBCs.

Masing-masing unit memiliki jumlah latihan yang berbeda. Tetapi memiliki komposisi yang serupa yaitu bagian pengenalan materi, pengenalan dan latihan tata bahasa, teks percakapan, latihan membaca dan berbicara, latihan menyimak dan berbicara, latihan menulis dan berbicara, serta latihan-latihan berbicara berdasarkan task-based instruction. Pada bagian akhir setiap unit terdapat rangkuman materi dan daftar kosakata. Selain itu, bahan ajar ini memiliki komponen pendukung seperti cover, kata pengantar, petunjuk penggunaan, daftar isi, lampiran referensi gambar, dan buku pedoman bagi pengajar.

\section{Hasil Uji Coba Produk}

Pengembangan bahan ajar berupa draf 1 melalui proses validasi oleh ahli materi dan ahli media. Validasi dilakukan guna mengetahui tingkat kelayakan dan kualitas bahan ajar. Pada instrumen validasi tertera rentang nilai dari 1 hingga 5. Masing-masing nilai memiliki kategori yang menunjukkan tinggi rendahnya kualitas.

Tabel 4. Rentang Nilai dan Kategori Penilaian

\begin{tabular}{ccc}
\hline Rentang Nilai & Nilai & Kategori \\
\hline $4,1999<\mathrm{x}$ & $\mathrm{A}$ & Sangat Baik \\
$3,3999<\mathrm{x} \leq 4,1999$ & $\mathrm{~B}$ & Baik \\
$2,6000<\mathrm{x} \leq 3,3999$ & $\mathrm{C}$ & Cukup \\
$1,8000<\mathrm{x} \leq 2,6000$ & $\mathrm{D}$ & Kurang \\
$\mathrm{x} \leq 1,8000$ & $\mathrm{E}$ & Sangat Kurang \\
\hline
\end{tabular}

Penilaian yang diberikan oleh para ahli berdasarkan butir-butir yang terdapat pada tabel berikut:

Tabel 5. Validasi Kelayakan Materi

\begin{tabular}{lll}
\hline \multicolumn{1}{c}{ Komponen } & & \multicolumn{1}{c}{ Subkomponen } \\
\hline I. & Kelayakan Isi & A. Kesesuaian Uraian Materi dengan SK dan KD \\
& B. Keakuratan Materi \\
& C. Keberdayagunaan Materi \\
& D. Menumbuhkan Minat \\
& E. Latihan dan Praktik \\
\hline II. Kelayakan Bahasa & A. Keakuratan Penggunaan Bahasa \\
& B. Komunikatif \\
\hline III. Kelayakan Penyajian & C. Kesesuaian dengan Tingkat Perkembangan Peserta Didik \\
& A. Teknik Penyajian \\
& B. Pendukung Penyajian \\
& C. Strategi Penyajian \\
\hline
\end{tabular}

Tabel 6. Validasi Kelayakan Media

Kesesuaian ukuran dan bentuk huruf

\section{Indikator penilaian}

Keterbacaan teks

Ketepatan pemilihan dan komposisi warna

Kesesuaian pemilihan gambar/ foto/ ilustrasi dengan tema

Jumlah gambar/ foto/ ilustrasi memadai

Kesesuaian desain cover

Penggunaan kertas yang sesuai

Kelengkapan komponen pada bahan ajar (cover, kata pengantar, petunjuk penggunaan, daftar isi dan isi)

Kejelasan unit dan halaman

Penggunaan pola dan layout yang sama/ senada

Desain tampilan menarik

Ukuran buku proporsional 
LingTera, 2 (2), Oktober 2015 - 229

Sri Wahyu Widiati, Sugirin

Tabel 7. Validasi Media Video

Kejelasan dan kecepatan narasi

Indikator penilaian

Kesesuaian pemilihan gambar, foto, dan video dengan tema

Kesesuaian musik latar

Kejelasan bahasa yang digunakan

Materi mendukung tingkat pemahaman dan latihan

Materi pada video dinilai representatif

Petunjuk penggunaan video yang mudah dipahami

Tampilan muatan pada video yang menarik

Peniadaan komponen yang tidak penting dalam video

Berikut adalah hasil secara keseluruhan untuk validasi materi dari dua ahli dan validasi media dari tiga ahli: (1) Nilai rata-rata kelayakan materi adalah 4.76, kategori 'sangat baik'; (2) Nilai rata-rata kelayakan media adalah 4.31, kategori 'sangat baik'.

Grafik berikut ini menunjukkan hasil tersebut.

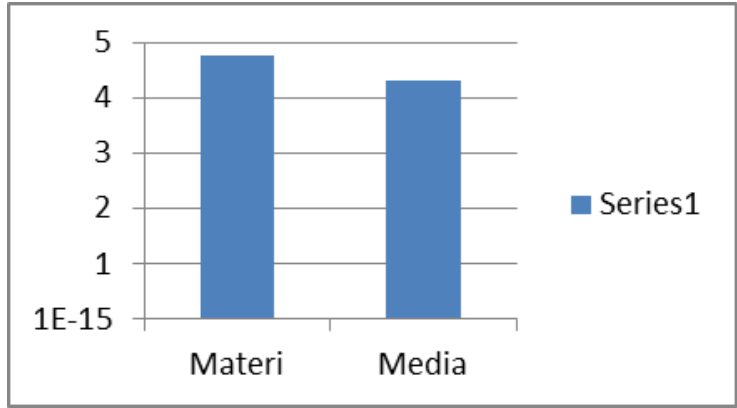

Gambar 2. Nilai Rata-Rata dari Validasi

Kelayakan Materi dan Media

Nilai kelayakan materi dan media tersebut merupakan rata-rata dari total nilai seluruh komponen dan subkomponen yang terdapat pada rubrik penilaian kelayakan materi dan media. Dapat disimpulkan bahwa nilai kelayakan materi lebih baik daripada nilai kelayakan media. Tetapi keduanya berada di dalam kategori 'sangat baik' untuk diaplikasikan di dalam pembelajaran.

Berikut ini adalah grafik yang menunjukkan hasil validasi materi secara garis besar menurut ketiga komponen yang telah disebutkan pada tabel. Melalui grafik ini, dapat diketahui perbandingan nilai yang diberikan oleh ahli materi 1 dan ahli materi 2 .

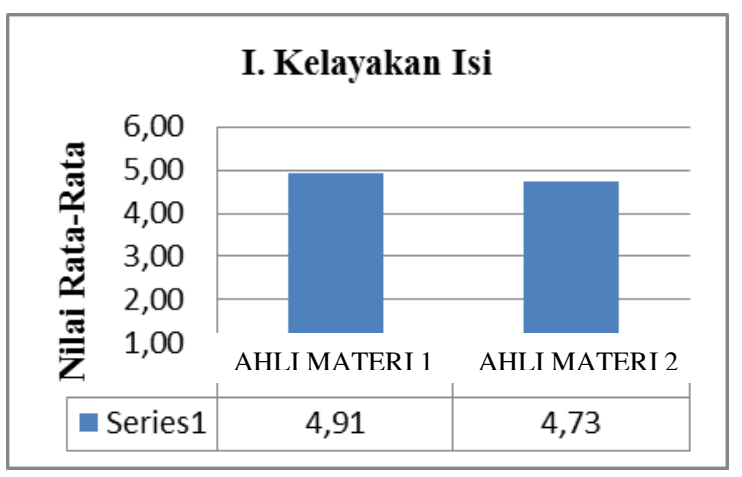

Gambar 3. Nilai Rata-Rata Komponen Kelayakan Isi Oleh Ahli Materi 1 dan 2

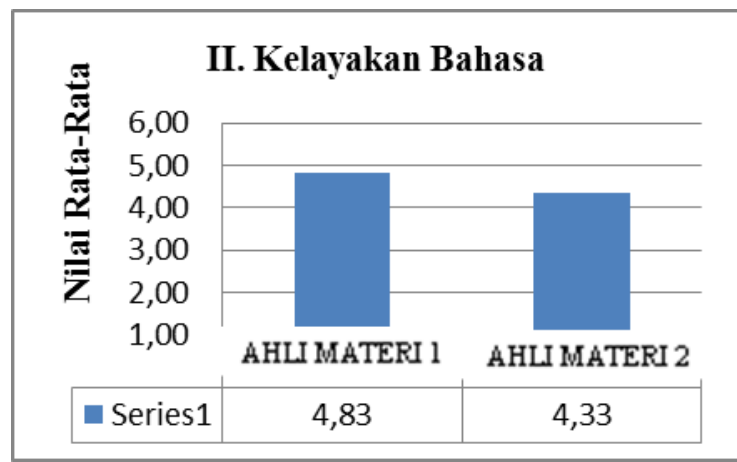

Gambar 4. Nilai Rata-Rata Komponen Kelayakan Bahasa Oleh Ahli Materi 1 dan 2

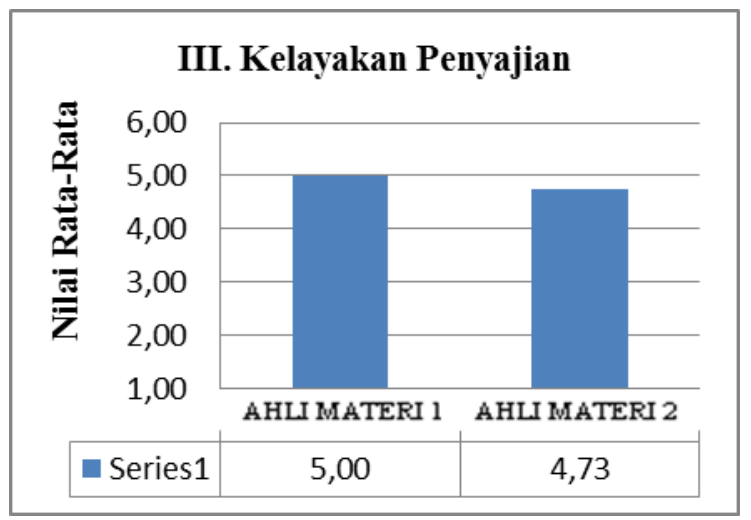

Gambar 5. Nilai Rata-Rata Komponen Kelayakan Penyajian Oleh Ahli Materi 1 dan 2

Validasi media dibagi menjadi dua kategori sesuai produk yang dikembangkan. Dua 
kategori tersebut adalah media buku dan media video. Produk bahan ajar dicetak menjadi buku, dan memiliki sebuah media audiovisual yang direkam ke dalam compact disk. Grafik-grafik di bawah ini menunjukkan perbandingan hasil validasi dari ketiga ahli media.

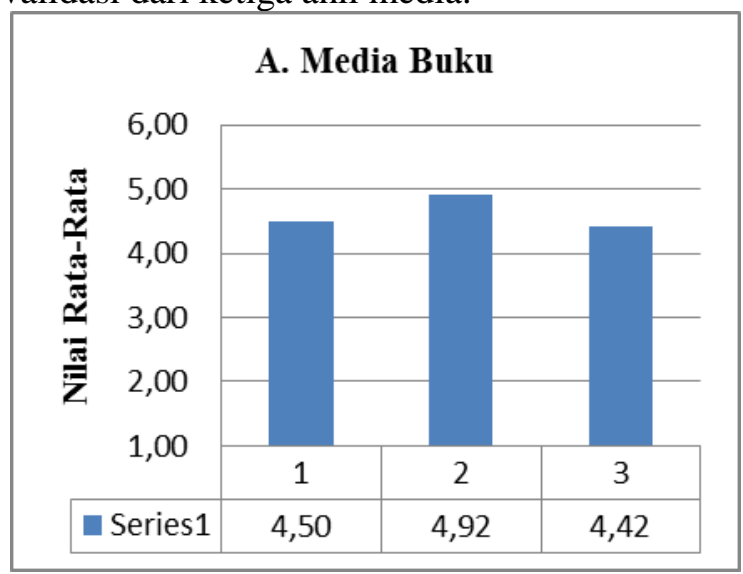

Gambar 6. Nilai Rata-Rata Validasi Media Berbentuk Buku Oleh Ahli Media 1, 2, dan 3

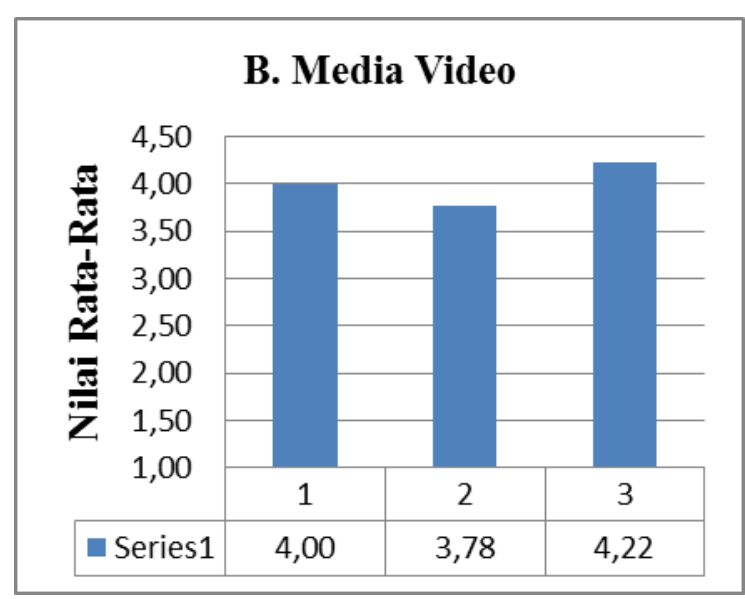

Gambar 7. Nilai Rata-Rata Validasi Media Berbentuk Video Oleh Ahli Media 1, 2, dan 3

Para ahli selain memberikan penilaian secara kuantitatif juga memberikan saran perbaikan atau revisi. Tabel 8 ini menunjukkan hasil keputusan revisi oleh para ahli.

Tabel 8. Keputusan Revisi dari Para Ahli

\begin{tabular}{cl}
\hline Pemberi Nilai & Keputusan \\
\hline Ahli Materi 1 & Tidak Revisi \\
Ahli Materi 2 & Tidak Revisi \\
Ahli Media 1 & Revisi \\
Ahli Media 2 & Tidak Revisi \\
Ahli Media 3 & Tidak Revisi \\
\hline
\end{tabular}

Hasil validasi dan saran dari para ahli dijadikan pedoman untuk memperbaiki draf 1 . Draf yang telah direvisi kemudian akan digunakan di dalam pembelajaran uji coba terbatas. Kedua ahli materi tidak menyarankan adanya revisi dan menyatakan draf 1 telah layak digunakan. Salah satu ahli media menyatakan draf harus direvisi dengan menambahkan rangkuman materi pada setiap unit.

Draf 1 yang digunakan pada uji coba terbatas kembali direvisi sesuai penilaian pengamat dan peserta didik. Hasil revisi menjadi draf 2 yang digunakan di dalam pembelajaran pada uji coba lapangan. Penilaian yang diperoleh pada uji coba lapangan menjadi acuan untuk merevisi draf kembali menjadi draf 3 atau produk akhir.

Revisi yang diperoleh dari masukan pengamat pada uji coba terbatas adalah menambahkan beberapa data mengenai informasi budaya pada panflet. Revisi lainnya baik pada uji coba terbatas maupun uji coba lapangan adalah penambahan tanda fonetik atau tanda baca Kanji dan penambahan arti kata di dalam tabel daftar kosakata.

Pada uji coba terbatas dan uji coba lapangan, peneliti bertindak selaku pengajar. Instruktur bahasa dan dosen pengampu bertindak sebagai pengamat. Tugas dari pengamat adalah mengisi lembar observasi kegiatan pembelajaran dan memberikan penilaian terhadap kemampuan peserta didik ketika melakukan kegiatan evaluasi. Baik pengamat maupun peserta didik juga mengisi instrumen kelayakan materi dan media. Hasil penilaian tersebut seluruhnya menyatakan baik materi maupun media, layak digunakan di dalam pembelajaran.

Dari berbagai hasil pemerolehan data-data kuantitatif yang diperoleh setelah penggunaan bahan ajar, salah satu hasil yang penting untuk dipaparkan di sini adalah hasil mengenai tingkat pemahaman oleh peserta didik.

Wawancara dilakukan kepada responden sebagai perwakilan dari para peserta didik. Responden dibagi menjadi ke dalam ketiga kelompok, yaitu kelompok dengan kemampuan bawah, menengah, dan atas. Responden untuk unit 1 sebanyak tiga mahasiswa dari enam mahasiswa yang hadir pada uji coba terbatas. Responden untuk unit 2, 3, dan 4 masing-masing sebanyak 6 mahasiswa. Setiap kelompok diwakili oleh dua mahasiswa. 
Sri Wahyu Widiati, Sugirin

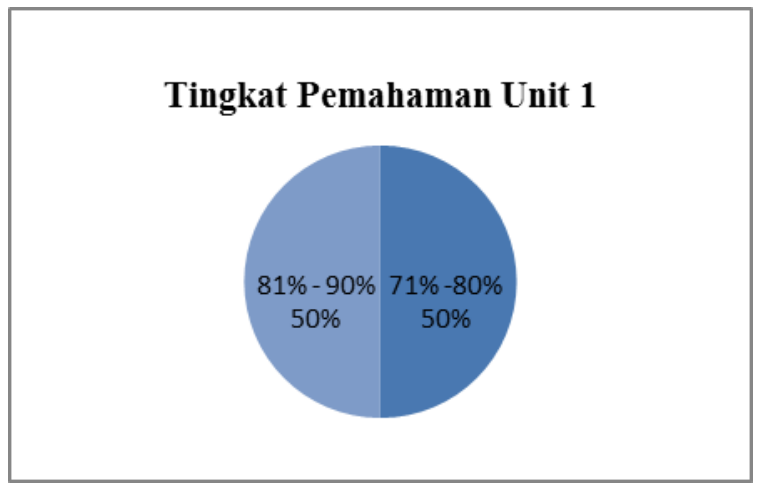

Gambar 8. Tingkat Pemahaman oleh Peserta Didik Terhadap Unit 1.

Tidak ada responden yang menyatakan tingkat pemahaman terhadap unit 1 di bawah $70 \%$ dan di atas 90\%. Separuh berada pada tingkat pemahaman $81 \%$ hingga $90 \%$, dan selebihnya $71 \%$ hingga $80 \%$.

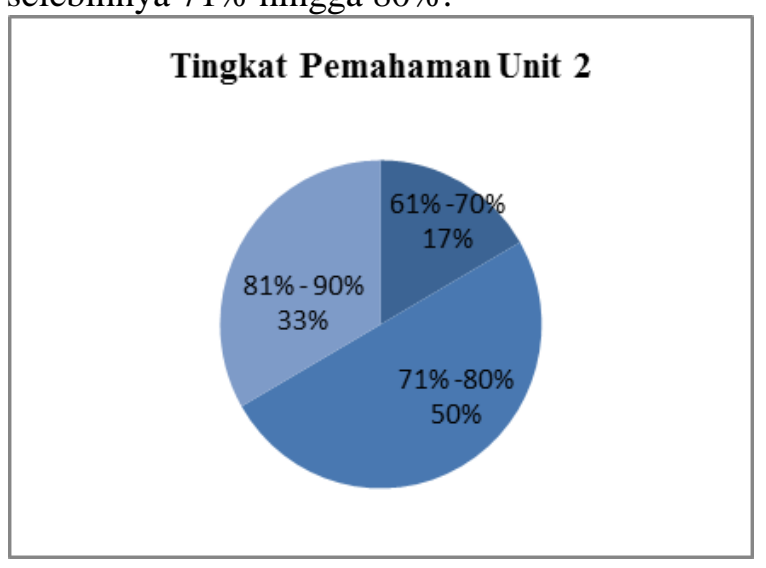

Gambar 9. Tingkat Pemahaman oleh Peserta Didik Terhadap Unit 2

$33 \%$ responden menyatakan memahami materi unit 2 sebesar $81 \%$ hingga 90\%, 17\% responden memahami materi unit 2 sebesar $61 \%$ hingga $70 \%$, dan $50 \%$ responden memahami materi unit 2 sebesar $71 \%$ hingga $80 \%$.

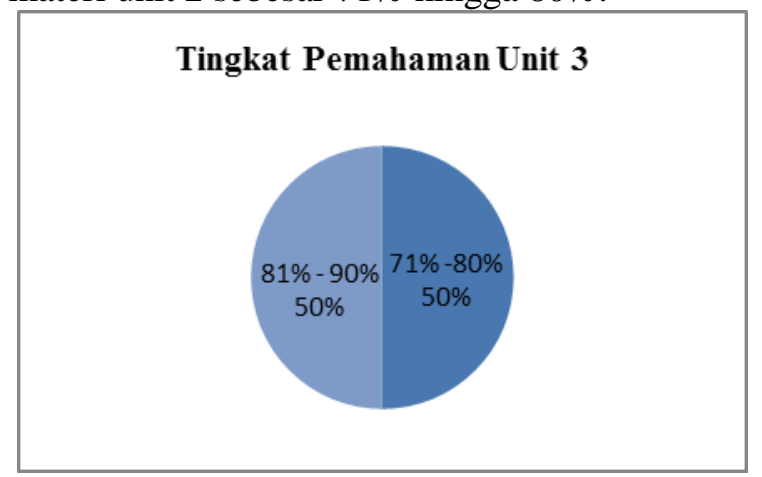

Gambar 10. Tingkat Pemahaman oleh Peserta Didik Terhadap Unit 3

$50 \%$ responden menyatakan memahami materi yang disajikan pada unit 3 sebesar $81 \%$ hingga $90 \%$, dan $50 \%$ responden lainnya menyatakan memahami materi unit 3 sebesar $71 \%$ hingga $80 \%$.

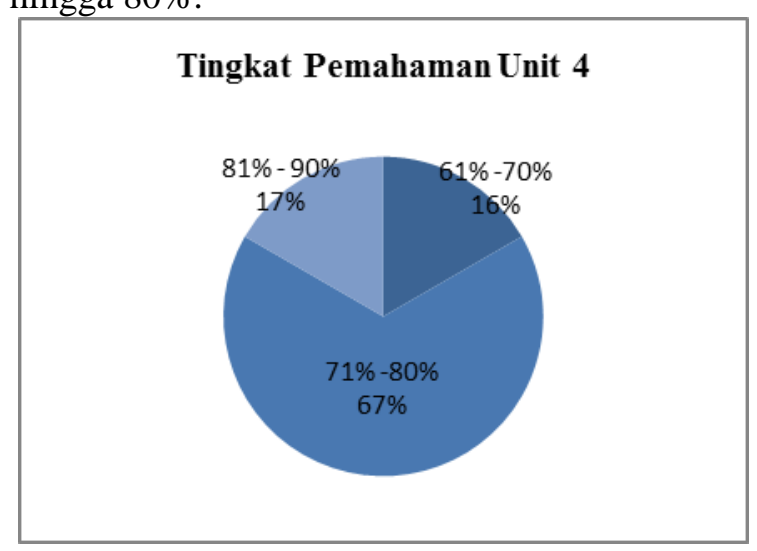

Gambar 10. Tingkat Pemahaman oleh Peserta Didik Terhadap Unit 4

Terdapat tiga tingkatan pemahaman terhadap unit 4 . Sebanyak $17 \%$ responden memahami materi unit 4 sebesar $81 \%$ hingga 90\%, 16\% responden memahami materi unit 4 sebesar $61 \%$ hingga $70 \%$, dan sebagian besar yaitu $67 \%$ responden memahami materi unit 4 sebesar $71 \%$ hingga $80 \%$.

\section{SIMPULAN}

Penelitian dan pengembangan yang dilakukan mengadaptasi prosedur dari Borg dan Gall, yaitu terdiri dari: (1) pengumpulan data, (2) perencanaan, (3) pengembangan produk, (4) validasi (uji ahli, uji coba awal/terbatas, uji coba lapangan) dan revisi, (5) menghasilkan produk akhir.

Digunakannya prosedur R \& D Borg dan Gall memudahkan proses pengembangan bahan ajar pada penelitian ini. Demikian halnya survei kebutuhan yang memberikan pedoman untuk mengembangkan silabus dan perencanaan pengembangan produk.

Produk yang dihasilkan terdiri dari lima unit yang disertai VCD. Setiap unit memiliki tema besar mengenai kebudayaan dan setiap latihan memiliki subtema yang berkaitan dengan tema besar tersebut. Setiap unit memiliki bentuk latihan yang sama yaitu latihan tata bahasa dan latihan empat keterampilan berbahasa. Standar tata bahasa yang digunakan adalah tingkat menengah. Latihan keterampilan berbicara atau kaiwa memperoleh fruekuensi lebih banyak. Latihan keterampilan berbicara pada bahan ajar ini mengadaptasi teori-teori fungsi berbicara, pembelajaran terpadu, pembelajaran berbasis tugas (task-based instruction), dan disesuaikan dengan kompetensi tingkat menengah. 
Sri Wahyu Widiati, Sugirin

Perolehan nilai validasi (uji coba ahli) materi dan media menunjukkan bahwa bahan ajar yang dikembangkan layak digunakan di dalam pembelajaran di kelas maupun pembelajaran mandiri. Nilai rata-rata kelayakan materi adalah 4.76, kategori 'sangat baik'. Nilai rata-rata kelayakan media adalah 4.31, kategori 'sangat baik'.

Berdasarkan kesan dan pernyataan dosen pengampu, materi-materi pada bahan ajar akan digunakan untuk pembelajaran pada perkuliahan sesuai kebutuhan. Kesan dan pernyataan peserta didik setelah menggunakan bahan ajar adalah bahan ajar dapat dimanfaatkan untuk pembelajaran secara mandiri.

\section{DAFTAR PUSTAKA}

Borg, W.R. \& Gall, M.D. (1983). Educational research. An introduction. New York: Longman Inc.

Hiesuji，Ｓ. (2007). 話すことを教える. Saitama: The Japan Foundation.

Iskandarwassid. \& Sunendar, D. (2011). Strategi pembelajaran bahasa. Bandung: PT. Remaja Rosdakarya.

Kaplan, D. \& Manners, A.A. (1999). Teori budaya. Yogyakarta: Pustaka Pelajar.
Koentjaraningrat. (2009). Pengantar ilmu antropologi. Edisi revisi 2009. Jakarta: Rineka Cipta.

Kurniawan, D. (2011). Pembelajaran terpadu: teori, praktik dan penilaian. Bandung: CV. Pustaka Cendikia Utama

Olajide, S.B. (2010). A critical assessment of the cultural content of two primary English textbooks used in Nigeria. Journal of language teaching and research. ISSN 1798-4769. Volume 1. Number 5. September 2010.

Richards, J.C. (2008). Teaching listening and speaking - from theory to practice. New York: Cambridge University Press.

Sukarjo.(2008). Kumpulan materi evaluasi pembelajaran. Prodi Teknologi Pembelajaran Universitas Negeri Yogyakarta.

Thornbury, S. (2005). How to teach speaking. UK: Pearson Education Ltd

Tickoo, M.L. (editor). (1995). Language and Culture in Multilingual Societies: Viewpoints and visions. Singapore: SEAMO Regional Language Center. 